\title{
Induksi Kalus dengan 2,4D dan BAP pada Eksplan Daun Vegetatif dan Generatif Tempuyung (Sonchus arvensis L.)
}

\author{
Shilfiana Rahayu ${ }^{1 *}$, Suharyanto ${ }^{2}$ \\ ${ }^{1}$ Program Studi Biologi, Fakultas Sains dan Teknologi, \\ Universitas Islam Negeri Sunan Kalijaga \\ Jl Marsda Adisucipto, Depok, Sleman, 55221, Indonesia \\ ${ }^{2}$ Fakultas Biologi, Universitas Gadjah Mada \\ Jl.Teknika Selatan,Skip Utara, Sleman, 55221, Indonesia \\ email: shilfiana.rahayu@uin-suka.ac.id
}

Rekam Jejak Artikel:
Diterima : $18 / 12 / 2020$
Disetujui : $21 / 12 / 2020$

\begin{abstract}
Tempuyung (Sonchus arvensis L.) is a plant that has many benefits and medicinal potential. This plant contains high flavonoids and terpenoids. The propagation of this plant is very important to do to provide medicinal ingredients on a prefabrication scale and to produce materials that have a high compound content. The tissue culture is one of the fastest ways in plant propagation and can increase the content of secondary metabolites in plants. The method to produce high compounds and produce somatic embryos in large quantities can be through callus culture. The research aim was to find the effect of 2,4D and BAP hormones and leaf explant variations on the growth of tempuyung callus. In this research, a combination of $2,4 \mathrm{D}(0 ; 0.5 ; 1 \mathrm{ppm})$ and $\mathrm{BAP}(0$; $0.5 ; 1 \mathrm{ppm}$ ) hormone was used in inducing callus, and explants used in this research were vegetative leaves and generative leaves of tempuyung. The results of this study showed that callus was produced within 10-14 days, with the friable callus texture and yellow in colour. Vegetative leaf explants initiate callus faster than generative leaves. Other results showed that the best combination in callus production was BAP $0.5 \mathrm{ppm}$ and $2.4 \mathrm{D} 1 \mathrm{ppm}$, and the most optimal leaf explants in producing callus were found in vegetative leaf explants
\end{abstract}

Key words: 2,3D, BAP, callus, leaf, tempuyung

\begin{abstract}
Abstrak
Tempuyung (Sonchus arvensis L.) merupakan tanaman yang memiliki banyak manfaat dan berpotensi sebagai obat. Tanaman ini diketahui memiliki kandungan flavonoid dan terpenoid yang tinggi. Propagasi tanaman ini sangat penting dilakukan untuk menyediakan bahan obat dalam skala prefabrikasi dan menghasilkan bahan yang memiliki kandungan senyawa yang tinggi. Metode kultur jaringan merupakan salah satu cara yang cepat dalam propagasi tanaman dan dapat meningkatkan kandungan metabolit sekunder dalam tanaman. Metode untuk menghasilkan senyawa yang tinggi dan menghasilkan somatik embrio dalam jumlah yang banyak dapat melalui kultur kalus. Penelitian ini bertujuan untuk mengetahui pengaruh hormon 2,4D dan BAP serta variasi eksplan daun terhadap pertumbuhan kalus tempuyung. Pada penelitian ini digunakan kombinasi hormon 2,4D $(0 ; 0,5 ; 1 \mathrm{ppm})$ dan $\operatorname{BAP}(0 ; 0,5 ; 1 \mathrm{ppm})$ dalam menginduksi kalus, dan eksplan yang digunakan pada penelitian ini adalah daun vegetatif dan daun generatif tempuyung. Hasil penelitian ini menunjukkan bahwa kalus dihasilkan dalam waktu 10-14 hari, dengan jenis kalus friabel dan berwarna kuning. Eksplan daun vegetatif lebih cepat inisiasi kalusnya dibanding daun generatif. Hasil lain menunjukkan bahwa kombinasi terbaik dalam produksi adalah BAP 0,5 ppm dan 2,4D $1 \mathrm{ppm}$, dan eksplan daun yang paling optimal dalam menghasilkan kalus terdapat pada eksplan daun vegetatif.
\end{abstract}

Kata kunci : 2,4D, BAP, daun, kalus, tempuyung. 


\section{PENDAHULUAN}

Indonesia memiliki banyak potensi tanaman obat yang belum banyak diteliti, sekurangkurangnya 9.600 spesies tumbuhan memiliki khasiat obat. Salah satunya adalah tempuyung (Sonchus arvensis L.) yang banyak ditemukan di seluruh wilayah Indonesia dan dikenal sebagai tanaman infasif (Utami, 2008). Tempuyung diketahui memiliki banyak manfaat untuk mengobati penyakit asma, bronchitis, batuk, dan memiliki aktivitas antibakteria, anti-inflamasi, antioksidan, diuretik, sedatif, dan hipnotik (Delyan, 2016).

Tempuyung mengandung triterpenoid, flavonoid, inositol, manitol dan kalsium. Kandungan metabolit tempuyung banyak terdapat di daun (Sulaksana et al., 2004). Daun tempuyung mengandung kandungan senyawa kimia seperti, flavonoid (kaemferol, luteolin-7-glukosida dan apigenin-7-O-glukosida), kumarin dan taraksasterol (Sriningsih et al., 2012). Kandungan total triterpenoid dalam daun tempuyung sebesar $64,79 \%$, sedangkan kandungan flavonoid total dalam daun tempuyung sebesar $14,04 \%$ dengan jenis yang terbesar adalah apigenin-7-O-glikosida (Rumondang et al., 2013). Menurut penelitian Sukandar dan Safitri (2016), penggunaan tempuyung sebagai obat termasuk aman bahkan jika digunakan untuk ibu hamil dan tidak menimbulkan efek samping.

Tempuyung merupakan tanaman tahunan yang bergetah, tumbuh liar di tempat terbuka yang terlindungi atau sedikit terkena sinar matahari dan perkembangbiakannya sangat cepat dan melalui biji yang mudah terbawa angin (Lumbanraja, 2009). Tempuyung tumbuh subur pada tanah berpasir atau menempel pada batu. Batang tanaman tempuyung, bergetah putih, percabangan monopodial, hijau keputih-putihan (Winarto, 2004). Daunnya tunggal, bagian bawah membentuk roset akar, bentuk lonjong atau lanset, tepi bergelombang, ujung runcing, panjang 5-50 cm, lebar 5-10 cm dan berwarna hijau (Wahyuni et al., 2019).

Pengambilan tanaman tempuyung di alam secara langsung dapat menimbulkan masalah hilangnya sumber plasma nuftah karena adanya kendala dalam budidayanya. Bahan herbal yang diedarkan di Indonesia pada saat ini, diduga sebagian besar bahan bakunya sudah mulai diimpor dari beberapa negara sehingga diperlukan peran bioteknologi untuk mengatasi masalah ini. Proses kultur jaringan dapat dilakukan memproduksi metabolit sekunder yang sama dengan metabolit sekunder yang diproduksi oleh tanaman aslinya, meski pada kondisi tertentu bisa menghasilkan senyawa yang berbeda (Katno \& Widiyastuti, 2004; Shyamkumar et al., 2007). Metode produksi senyawa aktif dan propagasi tanaman melalui teknik kultur jaringan melalui kultur kalus dipandang jauh lebih efisien jika dibandingkan dengan cara konvensional, karena didalamnya dapat dilakukan perekayasaan sehingga diperoleh senyawa aktif dengan kualitas yang lebih baik dan diproduksi tanaman yang lebih banyak dibandingkan dengan secara konvensional (Shyamkumar et al., 2007).

Pembentukan kalus dipengaruhi oleh jenis eksplan dan kombinasi Zat Pengatur Tumbuh (ZPT) pada medium kultur. Tipe eksplan yang berbeda akan memberikan respon yang berbeda terhadap kecepatan pembentukan dan pertumbuhan serta perkembangan kalus (Adil et al., 2018). Penggunaan hormon 2,4D dan BAP sudah banyak dilakukan untuk menghasilkan kalus pada tanaman (Aziz et $a l ., 2014)$. Menurut Indah dan Ermavitalini (2013), 2,4-D memiliki sifat lebih stabil dibanding dengan golongan auksin lainnya, karena tidak mudah terurai oleh enzim-enzim yang dikeluarkan oleh sel tanaman ataupun oleh pemanasan saat sterilisasi. Aziz, et al. (2014) menyebutkan BAP termasuk hormon sintetik dan memiliki sifat lebih stabil dan kuat dibandingkan jenis hormon sitokinin lainnya 
seperti kinetin dan zeatin. Hormon BAP berperan dalam perkembangan eksplan yaitu mamacu pembelahan sel, pembentukan tunas, dan multiplikasi tunas. Menurut Mahadi et al. (2014), hormon 2,4-D dapat merangsang pembentukan selsel. Penelitian ini bertujuan untuk mengetahui pengaruh hormon 2,4D dan BAP serta variasi eksplan daun terhadap pertumbuhan kalus tempuyung.

\section{MATERI DAN METODE}

Penelitian ini dilaksanakan pada bulan April hingga Oktober 2017 di Laboratorium Bioteknologi Fakultas Biologi Universitas Gadjah Mada. Bahan eksplan yang digunakan adalah daun vegetatif (daun yang membentuk roset) dan generatif (daun yang menempel pada tangkai bunga) pada tanaman Tempuyung (Sonchus arvensis L.). Bahan kimia yang digunakan antara lain: medium MS, hormon 2,4D dan BAP, akuades, alkohol 70\%, fungisida, klorox, $\mathrm{KOH}, \mathrm{HCl}$, aluminium foil, dan kertas saring steril. Konsentrasi media perlakuan pada penelitian ini merupakan kombinasi dari hormon 2,4D $(0,0.5,1 \mathrm{ppm})$ dan $\operatorname{BAP}(0,0.5,1 \mathrm{ppm})$, sehingga ada 9 perlakuan dan terdapat 5 ulangan pada masing-masing perlakuan.

Eksplan disterilisasi menggunakan rendaman fungisida dengan konsentrasi $4 \mathrm{~g} / \mathrm{L}$ selama 15 menit, setelah itu dibilas dengan aquades steril. Selanjutnya adalah sterilisasi di dalam LAF, eksplan direndam dalam larutan klorox $15 \%$ selama 15 menit, setelah itu dibilas dengan akuades steril. Eksplan hasil sterilisasi ditiriskan di atas kertas saring, lalu dipotong persegi dengan ukuran $\pm 1 \mathrm{~cm}$. Potongan eksplan ditanam di dalam botol kultur dan ditutup dengan aluminium foil. Kultur diinkubasi pada suhu $20^{\circ} \mathrm{C}$ dengan waktu periodisasi 24 jam selama 31 hari. Parameter yang diamati pada kultur kalus antara lain, warna kalus, tekstur kalus, waktu terbentuknya kalus, dan jumlah kalus. Data dianalisis secara kualitatif dengan mengambil gambar foto kultur.

\section{HASIL DAN PEMBAHASAN}

\section{Lama Waktu Pembentukan Kalus dan Persentase Pembentukan Kalus Tempuyung (Sonchus arvensis L.)}

Lama waktu pembentukan dan persentase pembentukan kalus pada daun vegetatif dan generatif tempuyung dapat dilihat pada Tabel 1 . Hasil penelitian menunjukkan bahwa lama waktu pembentukan kalus dapat bervariasi tergantung pada media pertumbuhan dan jenis eksplan yang digunakan (Marlin et al., 2012). Pemilihan hormon 2,4D dan BAP dalam penelitian ini dikarenakan kedua hormon ini merupakan hormon auksin dan sitokinin yang stabil, tidak mudah terurai akibat sterilisasi dan rusak oleh enzim yang dikeluarkan oleh eksplan (Indah \& Ermavitalini, 2013).

Pada penelitian ini lama waktu pembentukan kalus sekitar 10-14 hari. Waktu pembentukan paling cepat pada kedua eksplan terdapat pada perlakuan 2,4D 1 ppm (D1B0) yaitu terjadi pada hari ke-10. Secara umum lama waktu pembentukan kalus pada kedua eksplan hampir bersamaan, tetapi pada perlakuan D0.5B1, D1B0.5 dan D1B1 eksplan daun vegetatif lebih cepat terbentuk. Hasil ini berkaitan dengan struktur morfologi dan anatomi daun tempuyung. Pada daun vegetatif memiliki struktur yang lebih lunak dan tebal, jaringan penyusunnya sebagian besar berupa parenkim, sedangkan daun generatif strukturnya lebih kaku dan kasar, jaringan sklerenkim lebih banyak ditemukan pada organ ini (Wahyuni et al., 2019).

Jaringan parenkim lebih mudah membentuk kalus dibandingkan jaringan sklerenkimatis sehingga pembentukan kalus dari daun vegetatif lebih mudah. Pada umumnya kemampuan pembentukkan kalus dari jaringan tergantung dari, umur fisiologi dari jaringan waktu diisolasi, musim pada waktu bahan tanaman diisolasi, bagian 
BioEksakta: Jurnal Ilmiah Biologi Unsoed

Volume 2, Nomor 3 (2020) : 479 - 486

tanaman yang dipakai, dan jenis tanaman. Kalus dapat diinisiasi dari hampir semua bagian tanaman, tetapi organ yang berbeda menunjukkan kecepatan pembelahan sel yang berbeda pula.

Pada media MS0 dan BAP 0,5 ppm (D0B0.5) tidak ada pertumbuhan kalus, sedangkan persentase pembentukan kalus pada media lainnya mencapai $100 \%$ dari eksplan yang ditumbuhkan. Pada perlakuan kontrol (MS0), kedua eksplan tidak tumbuh kalus dan daun hanya melekuk. Hal ini disebabkan medium MS0 tidak mengandung ZPT atau zat organik yang dapat menginduksi kalus. Selain itu menurut Gunawan \& Mulyani (2004) konsentrasi hormon endogen dalam tanaman tidak mencukupi untuk pembentukan kalus.

Tabel 1. Waktu pembentukan kalus dan persentase terbentuknya kalus tempuyung dengan hormon 2,4D dan BAP pada eksplan daun vegetatif dan generatif

\begin{tabular}{clcccc}
\hline \multirow{2}{*}{ No. } & \multirow{2}{*}{ Perlakuan } & \multicolumn{2}{c}{ Waktu terbentuk kalus (hari ke-) } & \multicolumn{2}{c}{ Persentase pembentukan kalus $(\%)$} \\
\cline { 3 - 6 } & Daun vegetatif & Daun generatif & Daun vegetatif & Daun generatif \\
\hline 1 & MS0 & 0 & 0 & 0 & 0 \\
2 & D0B0,5 & 0 & 0 & 0 & 0 \\
3 & D0B1 & 14 & 14 & 100 & 100 \\
4 & D0,5B0 & 14 & 14 & 100 & 100 \\
5 & D0,5B0,5 & 14 & 14 & 100 & 100 \\
6 & D0,5B1 & 10 & 12 & 100 & 100 \\
7 & D1B0 & 10 & 10 & 100 & 100 \\
8 & D1B0,5 & 10 & 12 & 100 & 100 \\
9 & D1B1 & 10 & 12 & 100 & 100 \\
\hline
\end{tabular}

Catatan:

$\mathrm{D}=2,4$

$\mathrm{B}=\mathrm{BAP}$

Induksi kalus pada tanaman tempuyung tergolong cepat yaitu 10 hari, sama halnya dalam penelitian Lizawati et al. (2012) yang menggunakan hormon 2,4D dan BAP dalam menginduksi kalus pada daun durian dalam waktu cepat yaitu 8 hari. Perlakuan terbaik dalam menginduksi kalus pada kedua eksplan terdapat pada perlakuan 2,4D $1 \mathrm{ppm}$ (D1B0) yaitu selama 10 hari. Secara umum pembentukan kalus dari daun vegetatif lebih cepat dibandingkan dengan daun generatif. Setiap jenis eksplan dan tanaman yang berbeda memberikan respon yang berbeda dalam induksi kalus (Marlin et al., 2012).

\section{Jumlah Kalus dan Morfologi Kalus Tempuyung (Sonchus arvensis L.)}

Jumlah kalus yang dihasilkan dari berbagai media 2,4D dan BAP pada eksplan daun vegetatif dan generatif dapat dilihat pada Tabel 2. Hasil menunjukkan bahwa jumlah kalus yang terbentuk dari eksplan daun vegetatif dan generatif pada minggu ke-3 setelah terbentuk kalus memiliki jumlah yang bervariasi. Secara umum pada kedua eksplan menunjukkan persentase pembentukan kalus yang sama, tetapi jumlah yang dihasilkan berbeda. 
Tabel 2. Jumlah kalus dan morfologi kalus tempuyung dengan hormon 2,4D dan BAP pada minggu ke-3

\begin{tabular}{|c|c|c|c|c|c|}
\hline \multirow[b]{2}{*}{ No. } & \multirow[b]{2}{*}{ Perlakuan } & \multicolumn{2}{|c|}{ Jumlah kalus } & \multicolumn{2}{|c|}{ Deskripsi morfologi kalus } \\
\hline & & $\begin{array}{c}\text { Daun } \\
\text { vegetatif }\end{array}$ & $\begin{array}{c}\text { Daun } \\
\text { generatif }\end{array}$ & Daun vegetatif & Daun generatif \\
\hline 1 & MS0 & - & - & daun melekuk & daun melekuk \\
\hline 2 & D0B 0.5 & - & - & $\begin{array}{c}\text { daun melekuk dan tumbuh tunas dari } \\
\text { venasi }\end{array}$ & $\begin{array}{l}\text { daun melekuk dan tumbuh } \\
\text { tunas dari venasi }\end{array}$ \\
\hline 3 & D0B1 & ++ & + & kalus putih kekuningan dan friable & $\begin{array}{l}\text { kalus putih kekuningan dan } \\
\text { friable }\end{array}$ \\
\hline 4 & $\mathrm{D} 0.5 \mathrm{~B} 0$ & ++ & + & kalus kuning kecoklatan dan friable & kalus kuning dan friable \\
\hline 5 & $\mathrm{D} 0.5 \mathrm{~B} 0.5$ & ++ & + & kalus kuning dan friable & $\begin{array}{l}\text { kalus kuning kecoklatan dan } \\
\text { friable }\end{array}$ \\
\hline 6 & $\mathrm{D} 0.5 \mathrm{~B} 1$ & +++ & ++ & kalus kuning dan friable & kalus kuning dan friable \\
\hline 7 & D1B0 & ++++ & +++ & kalus kuning dan friable & kalus kuning dan friable \\
\hline 8 & D1B0.5 & +++++ & ++++ & kalus kuning dan friable & kalus kuning dan friable \\
\hline 9 & D1B1 & ++++ & +++ & kalus kuning dan friable & kalus kuning dan friable \\
\hline
\end{tabular}

Morfologi kalus yang terbentuk pada kedua eksplan hampir sama, yaitu sama-sama memiliki tekstur friabel pada semua perlakuan. Warna kalus setiap perlakuan juga bervariasi, tetapi sebagian besar berwarna kuning, hingga akhirnya mengalami pencoklatan sebagai tanda kematian jaringan kalus. Eksplan pada mulanya mengalami penggembungan, setelah itu terjadi akumulasi fenol yang menyebabkan warna kuning pada media, akumulasi fenol dalam jumlah yang banyak dapat merubah warna kalus menjadi coklat kehitaman. Warna kalus juga dapat mengindikasikan kondisi yang berbedabeda pada kalus. Warna kuning cerah menandakan kalus yang sehat, warna kemerahan dan kecoklatan menandakan kalus sudah dewasa, dan warna putih transparan menunjukkan kalus embrionik. Menurut Jannah et al. (2016) perubahan warna kalus disebabkan adanya perbedaan laju pertumbuhan pada kalus. Tekstur kalus friable dikarenakan sel-sel penyusun kalus berupa sel parenkim yang mempunyai ikatan yang renggang dengan sel-sel lain, sehingga mudah remah.
Kalus dapat dihasilkan dari organ yang telah dilukai, di dalam media yang mengandung hormon auksin dan sitokinin. Warna kalus dapat bermacammacam tergantung dari jenis sumber eksplan. Pada umumnya untuk eksplan yang mempunyai kambium tidak membutuhkan penambahan ZPT untuk menginduksi terbentuknya kalus karena secara alamiah pada jaringan berkambium yang mengalami luka akan tumbuh kalus untuk menutupi luka yang terbuka. Namun pada penelitian ini kalus tidak bisa diinduksi tanpa adanya hormon pertumbuhan.

Suatu sifat yang diamati dalam jaringan yang membentuk kalus adalah bahwa pembelahan sel tidak terjadi pada semua sel dalam jaringan asal, tetapi hanya sel di lapisan perifer yang membelah terus menerus, sedangkan sel-sel yang di tengah tetap quiscent atau diam. Gambar 1 menunjukkan pertumbuhan kalus dimulai dari bagian perifer atau tepi, kemudian berkembangan ke bagian tengah. 


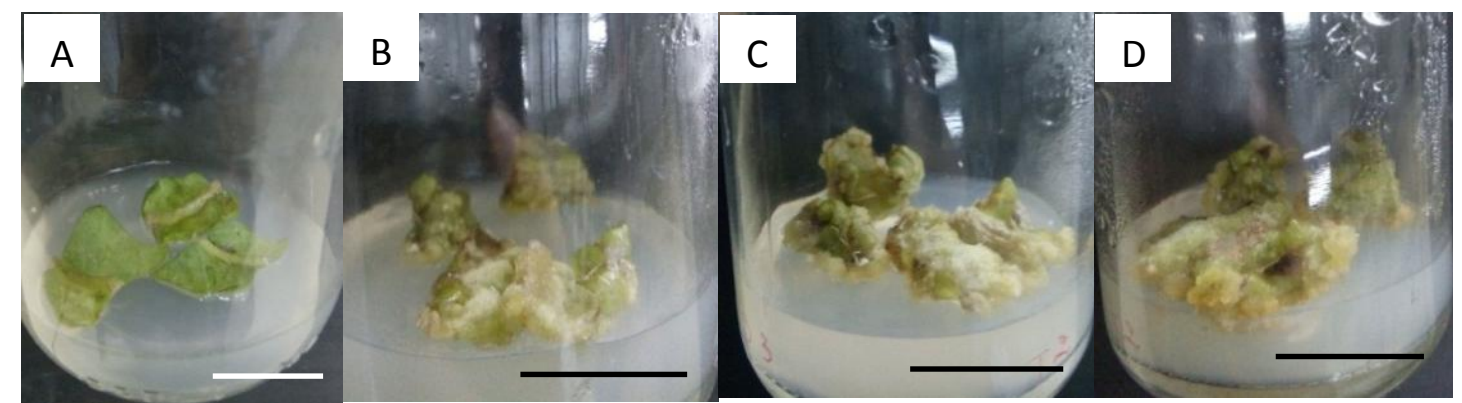

Gambar 1. Perkembangan kalus daun vegetatif tempuyung pada media 2,4D 1 ppm + BAP 0,5 ppm selama 31 hari. A. Hari ke-10, B. Hari ke-17, C. Hari ke-24, D. Hari ke-31. Bar $=1 \mathrm{~cm}$.

Perlakuan BAP 0,5 ppm dapat menginduksi tunas pada bagian venasi, dikarenakan hormon BAP merupakan hormon sitokinin yang dapat menginduksi tunas pada jaringan tanaman dan pada konsentrasi $0,5 \mathrm{ppm}$ secara tunggal dapat menginduksi tunas pada tanaman tempuyung. Pembentukan tunas terjadi pada kedua jenis eksplan, tetapi jumlah tunas yang terbentuk lebih banyak pada eksplan daun vegetatif. Menurut Wahyuningtyas et al. (2014), morfogenesis pada tanaman tergantung pada jumlah hormon eksogen dan endogen pada tanaman. Perlakuan BAP 1 ppm menginduksi kalus berwarna kuning keputihan dalam jumlah yang sedikit dan pembentukannya lama, sama halnya dengan perlakuan 2,4D 0,5 ppm + BAP 0,5 ppm dan 2,4D 0,5 ppm.

Kalus yang dihasilkan pada perlakuan 2,4D 0,5 ppm+BAP 0,5 ppm berwarna kuning, sedangkan kalus yang dihasilkan dari perlakuan 2,4D 0,5 ppm lebih mudah mencoklat. Perlakuan 2,4D 0,5 ppm + BAP $1 \mathrm{ppm}, 2,4 \mathrm{D} 1 \mathrm{ppm}, 2,4 \mathrm{D} 1 \mathrm{ppm}+\mathrm{BAP} 0,5$ ppm dan 2,4D $1 \mathrm{ppm}+\mathrm{BAP} 1 \mathrm{ppm}$ sama-sama menghasilkan kalus berwarna kuning dan waktu induksinya cepat. Sejalan dengan penelitian Amaniar (2014), kombinasi hormon 2,4D dan BAP menghasilkan kalus dengan warna segar, yaitu kuning kehijauan, Hal ini dikarenakan adanya pigmen dan klorofil pada kalus yang dikultur pada media kombinasi 2,4D dan BAP.

Menurut Karjadi \& Buchory (2007), hormon auksin dan sitokinin mempengaruhi pertumbuhan dan morfogenesis tumbuhan dalam kultur sel, jaringan, dan organ tanaman. Interaksi antar ZPT yang diberikan dalam media dan diproduksi oleh sel secara endogen akan menentukan arah pertumbuhan. Media pertumbuhan yang diberikan penambahan ZPT, menyebabkan kalus dapat tumbuh maksimal setelah 31 hari atau minggu ke-3 setelah terbentuknya kalus.

Hormon 2,4D memberikan pengaruh terhadap perkembangan sel karena auksin dapat meningkatkan permeabilitas sel (Wahyuningtyas et al., 2014), meningkatkan sintesis protein, tekanan osmotik sel, plastisitas dan meningkatkan pengembangan dinding sel (Abidin, 1994). Hormon BAP sebagai sitokinin berfungsi dalam sintesis protein dan pembelahan sel. Peningkatan pembelahan sel dan sintesis protein mengakibatkan sel berproliferasi dengan cepat dan meningkatkan volume sel, sehingga berat akan meningkat.

Eksplan daun vegetatif menghasilkan kalus yang lebih banyak dibandingkan dengan eksplan daun generatif. Perlakuan dengan jumlah kalus terbanyak terdapat pada perlakuan 2,4D $1 \mathrm{ppm}+$ BAP 0.5 ppm (D1B0.5), hal ini dikarenakan pada perlakuan ini perpaduan komposisi auksin dan sitokinin optimal untuk digunakan sebagai media pertumbuhan kalus. Hasil ini sesuai dengan pendapat Marlin et al., (2012), diperlukan konsentrasi auksin yang tinggi dalam merangsang pembentukan kalus. 


\section{SIMPULAN}

Kombinasi hormon 2,4D dan BAP dapat menginduksi kalus pada eksplan daun tempuyung. Kalus daun yang dihasilkan bertekstur vriabel dan berwarna kuning hingga kecoklatan. Media terbaik dalam pertumbuhan kalus adalah kombinasi 2,4D 0,5 ppm dan BAP 1 ppm karena menghasilkan kalus dalam waktu yang cepat, kalus segar dan berjumlah banyak, dan eksplan terbaik untuk menginduksi kalus adalah daun vegetatif.

\section{UCAPAN TERIMA KASIH}

Ucapan terimakasih diucapkan pada Fakultas Biologi UGM dan Bantuan Operasional Perguruan Tinggi Negeri (BOPTN), yang telah memberikan fasilitas dan dana penelitian untuk mendukung keberhasilan penelitian ini.

\section{DAFTAR REFERENSI}

Abidin, Z. 1994. Dasar-Dasar Pengetahuan Tentang Zat Pengatur Tumbuh. Bandung: PT Angkasa : 85 .

Adil, M., Ren, X., Kang, D.I., Thi, L.T., Jeong, B.R. 2018. Effect of explant type and plant growth regulators on callus induction, growth and secondary metabolites production in Cnidium officinale Makino. Molecular Biology Reports, 45(6): 1919-1927.

Aziz, M.M., Ratnasari, E., Rahayu, Y.S. 2014. Induksi kalus umbi iles-iles (Amorphophallus muelleri) dengan kombinasi 2,4-D dan BAP secara in vitro. Lentera Bio, 3(2): 109-114.

Delyan, E. 2016. Analysis of the composition of volatile compounds of field sow thistle (Sonchus arvensis L.) leaves using the method of gas chromatography with mass-detection. Pharm Inno, 5: 118-121.

Gunawan, D., Mulyani, S. 2004. Ilmu Obat Alam (Farmakognosi) Jilid I. Jakarta: Penerbit Penebar Swadaya.

Indah, P.N. dan Ermavitalini, D. 2013. Induksi daun nyamplung (Calophyllum inophyllum Linn.) pada beberapa kombinasi konsentrasi 6benzylaminopurine (BAP) dan 2,4dichlorophenoxyacetic acid (2,4-D). Jurnal Sains dan Seni Pomits, 2 (1): 2337-3520

Jannah, R., Suwirmen, Noli, Z.A. 2016. Pengaruh Pemberian Elisitor $\mathrm{Cu}^{2+}$ terhadap Kalus Artemisia vulgaris dalam Upaya Penyediaan Artemisinin sebagai Antimalaria. Prosiding Seminar Nasional Masyarakat Biodiversitas Indonesia. 26 September 2016. Samarinda: 2(2): 155-158.
Karjadi, A.K. dan Buchory, A. 2008. Pengaruh komposisi media dasar, penambahan BAP, dan pikloram terhadap induksi tunas bawang merah. Jurnal Hortikultura, 18(1):1-9.

Katno, dan Widiyastuti Y. 2004. Analisis kualitatif kandungan kimia kalus Sonchus arvensis L. hasil pertumbuhan secara kultur jaringan. Media Litbang Kesehatan, 14 (1).

Lizawati, N dan Desfira, R. 2012. Induksi kalus eksplan daun durian (Durio zibethinus Murr.cv. Selat Jambi) pada beberapa kombinasi 2,4-D dan BAP. Bioplantae, 1(1): 2302-6472.

Lumbanraja, L.B. 2009. Skrining Fitokima dan Uji Efek Antiinflamasi Ekstrak Etanol Daun Tempuyung (Sonchus arvensis L.) terhadap Radang pada Tikus. [Skripsi] Fakultas Farmasi, Universitas Sumatera Utara, Medan. [Indonesia].

Mahadi, I., Syafi'I, W., Sari, Y. 2016. Induksi kalus jeruk kasturi menggunakan hormon 2,4d dan BAP dengan metode in vitro. Jurnal Ilmu Pengetahuan Indonesia, 21(2):84-89.

Marlin, Yulian, Hermansyah. 2012. Inisiasi kalus embriogenik pada kultur jantung pisang curup dengan penambahan sukrosa, BAP dan 2,4-D. Jurnal Agrivor, 11 (2): 275-283.

Rumondang, M, Kusrini, D., Fachriyah, E. 2013. Isolasi, identifikasi, dan uji antibakteri senyawa triterpenoid dari ekstrak n-heksana daun tempuyung (Sonchus arvensis L.). Chem Info, 1 (1): 56-164.

Shyamkumar, B., Anjaneyulu, C., Giri, C.C. 2007. Genetic transformation of Terminalia chebula Retz. and detection of tannin in transformed tissue. Current Science, 92 (3).

Sriningsih, Adji, H.W., Sumaryono, W., Wibowo, A.E., Caidir, Firdayani, Kusumaningrum, S., dan Kartakusuma, P. 2012. Analisa Senyawa Golongan Flavonoid Herba Tempuyung (Sonchus arvensis L.). [Laporan Penelitian]. Pusat P2 Teknologi Farmasi dan Medika Deputi Bidang TAB BPPT. Jakarta. [Indonesia].

Sukandar, E.Y. and Safitri, D. 2016. Evaluation of teratogenic effect of tempuyung (Sonchus arvensis) extract on Wistar Rats. International Journal of Pharmacognosy and Phytochemical Research, 8(5):761-766.

Sulaksana, J., Budi, S., Dadang, I.J. 2004. Tempuyung Budi Daya Dan Pemanfaatan Untuk Obat. Cetakan pertama. Jakarta: Penerbit Swadaya.

Utami, P. 2008. Buku Pintar Tanaman Obat 431 Jenis tanaman Penggemar Aneka Penyakit. Jakarta: Penerbit Agromedia Pustaka.

Winarto, W.P. 2004. Tempuyung Tanaman Penghancur Batu Ginjal. Depok: Agromedia Pustaka.

Wahyuni, D.K, Rahayu, S., Purnama, P.R., Saputro, T.B., Suharyanto, Wijayanti, N., Purnobasuki, H. 2019. Morpho-anatomical structure and DNA barcode of Sonchus arvensis L. Biodiversitas, 20 (8): 24172426. 
BioEksakta: Jurnal Ilmiah Biologi Unsoed

Volume 2, Nomor 3 (2020) : 479 - 486

Wahyuningtyas, L., Resmisari, R.S., Nashichuddin. 2014. Induksi kalus akasia (Acasia mangium) dengan penambahan kombinasi 2,4D dan BAP pada media MS. Jurnal Biologi UIN Maulana Malik Ibrahim 